\title{
Analisa Sistem Informasi Akademik Menggunakan WebQual dan PIECES Frameworks Pada Universitas XYZ
}

\author{
Irdha Yunianto*, Hindriyanto Dwi Purnomo, Sri Yulianto Joko Prasetyo
}

Fakultas Teknologi Informasi, Prodi Magister Sistem Informasi, Universitas Kristen Satya Wacana, Salatiga, Indonesia Email: 1,*irdaynianto604@gmail.com, ${ }^{2}$ hindriyanto.purnomo@staff.uksw.edu, ${ }^{3}$ sri.yulianto@uksw.edu Email Penulis Korespondensi: irdaynianto604@gmail.com

Abstrak-Penelitian ini bertujuan untuk memberikan rekomendasi atau saran kebijakan guna peningkatan kualitas sistem informasi akademik (SIAKAD) bagi pengelola atau manajemen perguruan tinggi. SIAKAD merupakan aplikasi yang berbasis website yang dibuat untuk membantu proses pengelolaan data terkait akademik dan memiliki kegunaan dalam pengelolaan manajemen kampus atau perguruan tinggi. Saran kebijakan yang disusun berdasarkan analisa penilaian sistem informasi perguruan tinggi dengan perbandingan dimensi WebQual dan PIECES Framework dalam mengukur kualitas SIAKAD sebagai pedoman dalam meningkatkan atau mengembangkan kualitasnya menjadi lebih baik. Hasil analisa dengan menggunakan metode WebQual dengan nilai 3,50 dan PIECES Framework dengan nilai 3,97 terhadap kualitas website SIAKAD menghasilkan hasil yang sama dimana masuk kategori Baik dengan nilai skor $4(3,43-4,23)$ berdasarkan kriteria penilaian. Hasil rekomendasi pada penelitian ini diharapkan dapat memberikan kontribusi kepada manajemen perguruan tinggi sebagai salah satu bahan acuan atau pendukung keputusan dalam meningkatkan kualitas sistem informasi akademik (SIAKAD) berbasis website menjadi lebih baik lagi.

Kata Kunci: Universitas; Sistem Informasi; SIAKAD; WebQual; PIECES Frameworks

Abstract-This study aims to provide recommendations or policy suggestions in order to improve the quality of the academic information system (SIAKAD) for university operator or management. SIAKAD is a website-based application created to assist the process of managing data related to academics and has uses in managing campus or college management. Policy suggestions are compiled based on the analysis of higher education information system assessments with a comparison of the dimensions of WebQual and the PIECES Framework in measuring the quality of SIAKAD as a guide in improving or developing the quality for the better. The results of the analysis using the WebQual method with a value of 3.50 and the PIECES Framework with a value of 3.97 on the quality of the SIAKAD website produced the same results which were in the Good category with a score of $4(3.43-4.23)$ based on the assessment criteria. The results of the recommendations in this study are expected to contribute to higher education management as a reference or decision support in improving the quality of the website-based academic information system (SIAKAD) for the better.

Keywords: University; Information System; SIAKAD; WebQual; PIECES Frameworks

\section{PENDAHULUAN}

Era modern yang ditandai dengan perkembangan teknologi informasi digital, dimana internet dan telekomunikasi menjadi media utama masyarakat dalam berkomunikasi dan memperoleh informasi yang sering kita sebut Telematika.Sistem informasi memiliki peranan di berbagai lini usaha dan menjadi pilar utama dalam kegiatan operasional organisasi atau institusi.Teknologi informasi membuat dunia semakin kecil tanpa batas (limitless), aktifitasnya tanpa mengenal waktu (timeless). Setiap orang dimana saja dan kapan saja mampu mendapat informasi yang cepat dan akurat dengan perangkat teknologi yang dibawanya (smartphone). Pemanfaatan teknologi ini juga dilakukan perguruan tinggi, dikembangkan guna melakukan pelayanan akademik. Mahasiswa berkomunikasi dan memperoleh informasi akademik dari sistem informasi yang dikembangkan perguruan tinggi.

Sistem informasi merupakan sekumpulan beberapa komponen dari teknologi informasi yang saling menghasilkan sebuah informasi untuk mendapatkan satu jalur komunikasi dalam sebuah kelompok atau organisasi [1], [2]. Penerapan atau aplikasi dari sistem informasi bertujuan agar dapat membantu meningkatkan efektifitas dan efisiensi sebuah organisasi serta membantu individu/seseorang pada saat pengambilan keputusan [3]. Sistem Informasi berbasis website telah digunakan selama beberapa dekade dan banyak organisasi sangat bergantung pada mereka. Perguruan tinggi modern tidak bisa lepas dari sistem informasi akademik dalam pengelolaannya. Fungsi utama di balik sistem informasi adalah untuk menyimpan, mengelola, dan memproses data. Data dapat dihasilkan dari pihak terkait, dosen, karyawan, mahasiswa dan sumber lainnya. Sistem informasi akademik (SIAKAD) berbasis website semakin mendapat perhatian dari perguruan tinggi dan pengembang. Teknologi mutakhir menunjukkan fokus dari satu set halaman HTML ke sistem informasi berbasis website (SIBW) yang lebih mudah dikelola. SIBW berevolusi dari sistem dengan hypermedia intensif ke sistem berbasis database yang memiliki koneksi dekat dengan pengguna.

Era Globalisasi yang ditandai dengan meningkatnya kecepatan arus informasi yang didukung perkembangan teknologi, menjadikan teknologi informasi memiliki peran vital dalam meningkatkan kualitas layanan perguruan tinggi terhadap mahasiswa. Website Sistem informasi akademik (SIAKAD) di salah satu Universitas swasta di Semarang dirasakan memiliki banyak kekurangan antara lain informasi yang kurang pembaharuan, kurang tepat waktu, tampilan yg kurang menarik dan lain-lain. Untuk itu perlu dilakukan pengkajian menyangkut pada kualitas informasi, kualitas interaksi termasuk kualitas penggunaan dari website itu sendiri. Pelayanan SIAKAD bertujuan mengakomodasi kebutuhan civitas akademika dan kepentingan 
operasional kampus. Selama ini penggunaan SIAKAD dalam tampilan website yang masih dalam tahap pengembangan dan masih ada beberapa kekurangan, seperti tampilan website, sinkronisasi aspek kegunaan (usability), aspek kognitif, dll.

Sebuah riset [4] yang berjudul Evaluasi Usabilitas Layanan Sistem Informasi Akademik Berdasarkan Kombinasi ServQual dan Webqual di Politeknik XYZ, dimana sangat dibutuhkan sebuah evalusasi untuk mengukur efektivitas penggunaan SIAKAD agar dapat ditingkatkan serta dikembangkan kualitasnya. Hasil riset menunjukkan beberapa jika variabel subyektif (ServQual) dari indeks usabilitas ditingkatkan, maka variabel obyektif dari indeks usabilitas (WebQual) juga akan meningkat secara.

Berdasarkan penelitian [5] yang berfokus pada pelanggan layanan jaringan komunikasi 4G pada PT. XL Axiata Tbk. di wilayah kota Depok dengan metode PIECES framework yang terdiri dari 5 dimensi penilaian, yaitu performance, information, economic, control dan security, efficiency. Hasil penelitian ini diharapkan dapat meningkatkan pelayanan operasional secara langsung kepada users seperti help desk. Penelitian tentang pengukuran penggunaan website dengan judul Pengukuran Kualitas Website Sistem Informasi Akademik STIKOM Dinamika Bangsa Jambi [6], dimana tujuan penelitian ini untuk menilai kualitas website Sistem Informasi Akademik (SIAk) dengan menggunakan indikator WebQual versi 4.0 pada 97 orang responden dengan metode regresi liner berganda. Hasil riset menunjukkan variabel usability, information quality, dan service quality secara parsial berpengaruh signifikan dan positif terhadap kepuasan responden.

Perguruan tinggi merupakan institusi bisnis yang memberikan pelayanan kepada stakeholder nya sebagai pelanggan. Tujuan pelayanan bisnis adalah mencapai kepuasan pelanggan. Pelayanan perguruan tinggi terhadap mahasiswa sebagai penggunanya diantaranya melalui sistem informasi akademik (SIAKAD) berbasis website. Pelanggan yang puas adalah salah satu unsur utama untuk kesuksesan bisnis jangka panjang. Meningkatkan kepuasan pelanggan harus menjadi salah satu fokus utama bagi banyak bisnis terutama bisnis pendidikan. Kepuasan pelanggan dapat dicapai melalui berbagai elemen, dan untuk bisnis yang menyediakan layanan, kualitas layanan sangat penting. Dalam beberapa penelitian metode analisis sebuah website berupa WebQual berpengaruh pada quality service pengguna website [7]. Penting untuk mengkaji hubungan antara kualitas antara layanan elektronik dan kepuasan pelanggan [8].

Penelitian ini menggunakan metode WebQual dan PIECES Framework untuk mengukur kualitas Sistem informasi akademik (SIAKAD) berbasis website, berlandaskan persepsi pengguna yaitu mahasiswa. Model WebQual adalah alat analisa untuk mengukur kegunaan, kualitas informasi, dan kualitas interaksi layanan website. Sistem informasi akademik sangat dibutuhkan oleh institusi untuk memenuhi pelayanan kepada semua stakeholder (mahasiswa, dosen, administrasi, operator, dll) Sumber daya yang digunakan untuk metode WebQual terkait dengan penilaian Sistem Informasi [9].

Keterlibatan pengguna atau user sebuah website sangat diperlukan dalam memanfaatkan sebuah teknologi informasi [6]. Ketika ada pemenuhan yang sesuai dengan kebutuhan user terkait kualitas informasi suatu website maka tingkat kepuasan user juga akan tumbuh [10], [11]. Metode WebQual merupakan sebuah metode pengukuran kualitas website berdasarkan persepsi user atau pengguna [12]. Metode WebQual adalah sebuah pendekatan/metode yang berawal dari metode ServQual yang juga merupakan pengembangan dari Quality Function Development (QFD) method. [13]. Dalam pengukuran WebQual 4.0 terdiri dari 22 indikator terbagi dalam tiga dimensi [4], yaitu: aspek kegunaan (usability), kualitas informasi (information quality), dan interaksi layanan (service interaction). Persepsi pengguna akhir (end user) website dijadikan landasan penyusunan metode ini. WebQual memiliki total empat generasi skala, dan skala 2.0 menjadi yang pertama yang berfokus secara khusus pada kualitas layanan elektronik dan kepuasan pelanggan di bidang e-perpajakan.

Sedangkan PIECES Framework merupakan kerangka analisa yang digunakan untuk mengklasifikasikan suatu permasalahan, peluang dan pengarahan dalam analisa dan perancangan sistem informasi [14]. Dengan metode framework ini, sebuah sistem dapat diketahui kekurangan serta kelemahannya sehingga bisa dijadikan bahan pertimbangan dalam mengembangkan sebuah sistem yang bagus kedepannya bagi organisasi [15]. Metoda PIECES memiliki enam kategori [5], yaitu: Performance, Information/data, Economic, Control/security, Efficiency, dan Service.

\section{METODOLOGI PENELITIAN}

\subsection{Jenis Penelitian}

Kategori penelitian ini adalah penelitian deskriptif kuantitatif. Variabel-variabel yang digunakan pada penelitian ini adalah berdasarkan metode WebQual versi 4.0, yang terdiri dari tiga dimensi: kegunaan (usability), kualitas informasi (information quality), dan interaksi layanan (service interaction), dengan beberapa indikator. Analisis dengan metode PIECES Framework juga digunakan, yang terdiri dari performance, information/data, economic, control/security, efficiency, service dimana terdiri dari beberapa indikator.

\subsection{Populasi dan Sampel}


Dalam penelitian ini proses pengumpulan datanya dilakukan dengan survei menyebarkan kuesioner kepada responden. Populasi sampel yang digunakan dalam penelitian ini adalah mahasiswa universitas XYZ, yaitu merupakan salah satu perguruan tinggi di Jawa Tengah. Responden yang dipilih adalah responden dari kalangan mahasiswa yang menggunakan SIAKAD. Jenis pertanyaan dalam kuesioner berupa pertanyaan tertutup (close ended question).

\subsection{Teknik Pengambilan Sampel}

Metode pemilihan dalam penentuan sampel memakai metode Slovin dengan toleransi tingkat kesalahan sebesar 5\%. Populasi pengguna Sistem Informasi Akademik (SIAKAD) dalam periode 3 bulan (Juli s.d September 2019) sebanyak 1620 mahasiswa. Maka perhitungan jumlah sampel dilakukan dengan rumus Slovin [16] sebagai berikut :

$$
n=\frac{N}{1+e 2}
$$

Keterangan :

$n$ : jumlah sampel

$N$ : jumlah populasi

Jumlah Sampel $=1620 / 1+(1620 \times(0,05 \times 0,05))$, maka akan diperoleh sampel sebanyak 311 mahasiswa.

\subsection{Instrumen dan Metode Analisis Data}

Metode pengukuran diperlukan guna mengetahui hasil evaluasi website SIAKAD. Untuk menentukan penilaian pertanyaan pada kuesioner dipakai metode penilaian Skala Likert, dimana setiap butir pertanyaan dibagi menjadi lima (5) pilihan jawaban [17]. Skala Likert dipakai untuk menilai pertanyaan penelitian dalam kuesioner oleh responden dengan mengukur terkait pendapat, persepsi maupun sikap orang atau sekelompok individu [14]. Skala ini untuk mengukur sikap, pendapat dan persepsi seseorang atau sekelompok orang tentang fenomena. Tanggapan responden diukur atas pilihan terhadap masing-masing jawaban. Dimensi kualitas penilaian diberi skor sebagai berikut:

Tabel 1. Bobot Nilai (Skala Likert)

\begin{tabular}{lcc}
\hline \multicolumn{1}{c}{ Jawaban } & Kode & Nilai \\
\hline Sangat Setuju & SS & 5 \\
Setuju & S & 4 \\
Netral & N & 3 \\
Tidak Setuju & TS & 2 \\
Sangat Tidak Setuju & STS & 1 \\
\hline
\end{tabular}

Metode analisa datanya dengan cara menentukan nilai rata-rata (mean) setiap pertanyaan penelitian dalam kuisioner. Rumus untuk menentukan nilai rata-rata adalah :

$$
r=\frac{f}{n}
$$

Keterangan :

$r$ : nilai Rata-Rata

$f:$ frekuensi

$n$ : jumlah Responden

Penentuan karakteristik penilaiannya ditentukan dengan mengetahui nila interval kelasnya. Rumus yang digunakan untuk menentukan interval kelas adalah :

$$
i=\frac{r}{k}
$$

Keterangan :

i : Interval Kelas

$\mathrm{r}$ : Range (high scale-low scale)

k : Jumlah Kelas

Nilai interval kelas yang didapatkan adalah :

$$
i=\frac{r}{k}=\frac{5-1}{4}=0,8
$$

Maka tabel karakteristik penilaian didapat dengan nilai interval kelas 0,8 dengan kombinasi skala likert dan interval kelas seperti dalam tabel 2 berikut :

Tabel 2. Kriteria Penilaian

\begin{tabular}{ccc}
\hline Skor & Skala & Kategori \\
\hline 1 & $1,00-1,80$ & Sangat Buruk \\
2 & $1,81-2,61$ & Buruk
\end{tabular}


JURNAL MEDIA INFORMATIKA BUDIDARMA

Volume 5, Nomor 3, Juli 2021, Page 987-1007

ISSN 2614-5278 (media cetak), ISSN 2548-8368 (media online)

Available Online at https://ejurnal.stmik-budidarma.ac.id/index.php/mib DOI 10.30865/mib.v5i3.3046

\begin{tabular}{ccc}
\hline Skor & Skala & Kategori \\
\hline 3 & $2,62-3,42$ & Cukup \\
4 & $3,43-4,23$ & Baik \\
5 & $4,24-5,04$ & Sangat Baik \\
\hline
\end{tabular}

\subsection{Tahapan Penelitian}

Berikut tahapan penelitian dimensi WebQual dan PIECES framework yang terlihat pada gambar 1.

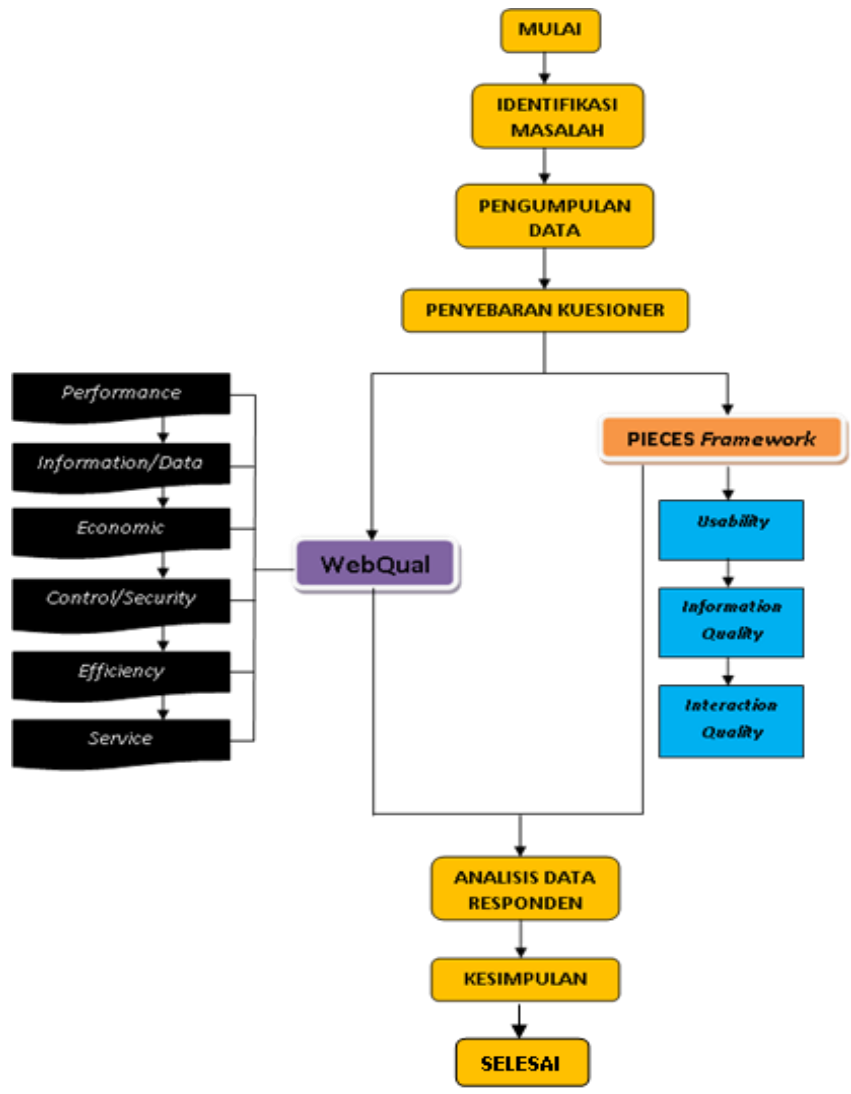

Gambar 1. Tahapan Penelitian

\section{HASIL DAN PEMBAHASAN}

\subsection{SIAKAD (Sistem Informasi Akademik)}

SIAKAD (Sistem Informasi Akademik) adalah aplikasi sistem yang dibangun berbasis website untuk memudahkan pengelolaan data akademik di perguruan tinggi sehingga tata kelola proses kegiatan akademik bisa dikelola dengan efektif dan efisien. Tampilan SIAKAD (Sistem Informasi Akademik) pada universitas XYZ dapat digambarkan pada gambar 2 .

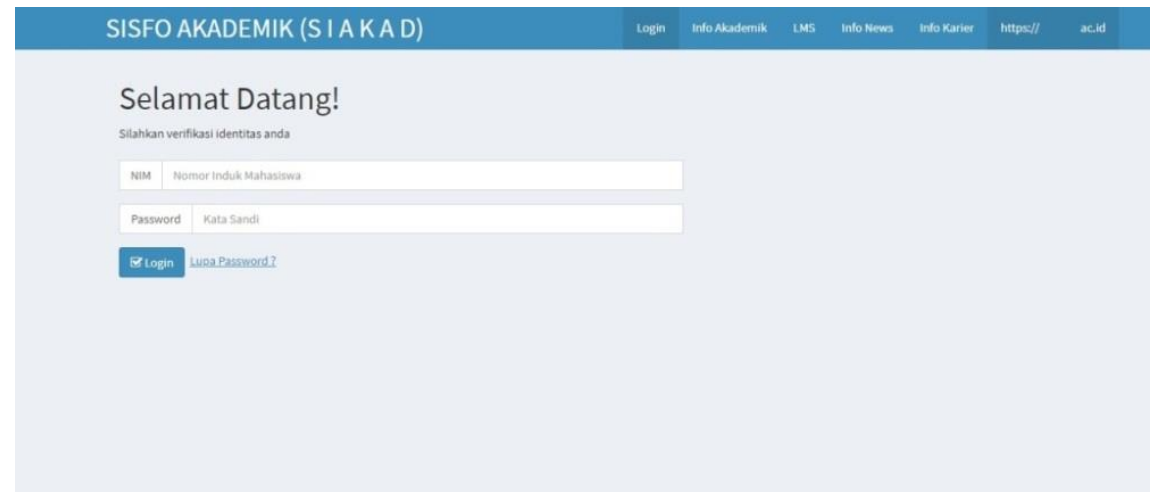

Gambar 2. SIAKAD Universitas XYZ 
Aplikasi SIAKAD pada universitas XYZ digunakan oleh seluruh civitas akademika yang terlibat dalam tata kelola data akademik, seperti mahasiswa, dosen, operator, BAAK, dll. Dengan adanya SIAKAD semua data akademik dapat dikelola dengan baik sehingga tercapai good corporate governence system. Bagi tenaga pengajar atau dosen, SIAKAD sangat membantu dalam mengelola penjadwalan mata kuliah, pemberian nilai dan interaksi dengan mahasiswa melalui fitur chat. Bagi mahasiswa, SIAKAD sangat membantu dalam berinteraksi dengan dosen terkait kendala baik teknis atau non teknis pada mata kuliah.

\subsection{Karakteristik Responden}

Responden yang digunakan dalam penelitian ini sebanyak 311 orang mahasiswa universitas XYZ. Karakteristik responden mahasiswa berdasarkan program studinya terdiri dari 39,87\% atau sepadan 124 orang mahasiswa Desain Grafis, 29,9\% mahasiswa Teknik Informatika atau sepadan 93 orang, 29,9\% mahasiswa Manajemen Informatika atau sepadan 62 orang dan $19.93 \%$ atau sepadan 32 orang mahasiswa Sistem Informasi yang terlihat pada gambar 3.

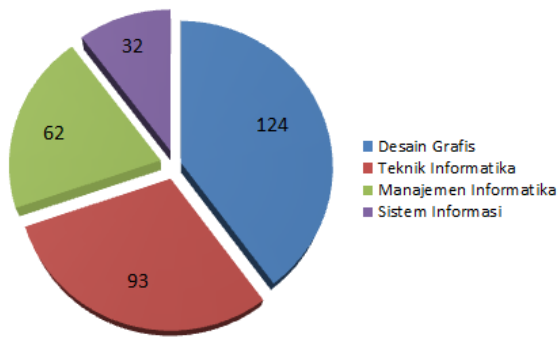

Gambar 3. Prosentase Karakteristik Program Studi Responden

Sedangkan karakteristik responden berdasarkan gender atau jenis kelamin dibagi dengan proporsi 55\% perempuan atau sebanyak 171 orang mahasiswi dan 45\% laki-laki atau sebanyak 140 orang mahasiswa yang terlihat pada gambar 4 .

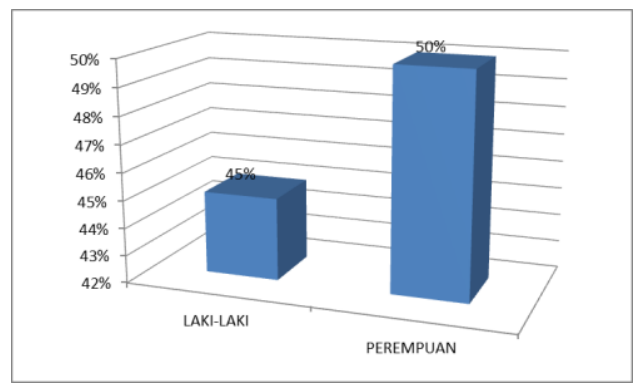

Gambar 4. Prosentase Karakteristik Jenis Kelamin Responden

\subsection{Hasil Analisa WebQual}

Analisa WebQual meliputi 3 dimensi, yaitu : kemudahan penggunaan (usability), Kualitas informasi (information quality), dan kualitas interaksi (interaction quality).

\subsubsection{Analisa Dimensi Usability}

Berdasarkan hasil analisis pada dimensi aspek kemudahan penggunaan (usability), jawaban dari responden terhadap 8 pertanyaan penelitian yang paling sering adalah menyatakan setuju, yaitu sebanyak 891 kali $(35,81 \%)$ dan jawaban sangat setuju sebanyak 435 (17,52\%). Jumlah jawaban keduanya muncul 1326 kali $(53,33 \%)$. Jawaban responden cenderung setuju terhadap aspek kemudahan dalam penggunaan.

Dalam tabel 3 nampak indikator yang mempunyai skor tertinggi menjadi perhatian bagi pengguna adalah indikator "Apakah desain sesuai dengan jenis website ?" (USA6) dipersepsikan dengan nilai tertinggi mencapai 3,62 (baik). Dua indikator hanya mendapatkan nilai cukup yaitu website mengandung kompetensi (USA7) dan website menciptakan pengalaman positif bagi pengguna (USA8). Hal ini perlu ditingkatkan kualitas usabilitas nya dalam kompetensi website dan penggunaanya merasa senang ketika menggunakan website siakad. Secara umum penilaian penggguna website SIAKAD memberikan nilai 3,52 dalam dimensi kemudahan penggunaan (usability) masuk dalam kategori baik.

Tabel 3. Indikator Dimensi Usability

\begin{tabular}{ccccc}
\hline Kode & Jumlah & Total & Mean & Kategori \\
\hline USA1 & 311 & 1122 & 3,61 & Baik \\
USA2 & 311 & 1121 & 3,60 & Baik \\
USA3 & 311 & 1097 & 3,53 & Baik \\
\hline
\end{tabular}


ISSN 2614-5278 (media cetak), ISSN 2548-8368 (media online)

Available Online at https://ejurnal.stmik-budidarma.ac.id/index.php/mib DOI 10.30865/mib.v5i3.3046

\begin{tabular}{ccccc}
\hline USA4 & 311 & 1115 & 3,59 & Baik \\
USA5 & 311 & 1078 & 3,47 & Baik \\
USA6 & 311 & 1126 & 3,62 & Baik \\
USA7 & 311 & 1045 & 3,36 & Cukup \\
USA8 & 311 & 1064 & 3,42 & Cukup \\
Jumlah & 2488 & 8768 & 3,52 & Baik \\
\hline
\end{tabular}

Berdasarkan grafik yang ditunjukkan gambar 5 terlihat 6 indikator yang dinilai baik oleh mahasiswa (USA1, USA2, USA3, USA4, USA5, USA6). Mahasiswa meerasa tidak kesulitan dalam mempelajari dan mudah memahami interaksi dalam website SIAKAD. Mereka juga merasa mudah menggunakannya dengan kemudahannya dalam bernavigasi. Desainnya sudah dianggap sesuai dan menarik.

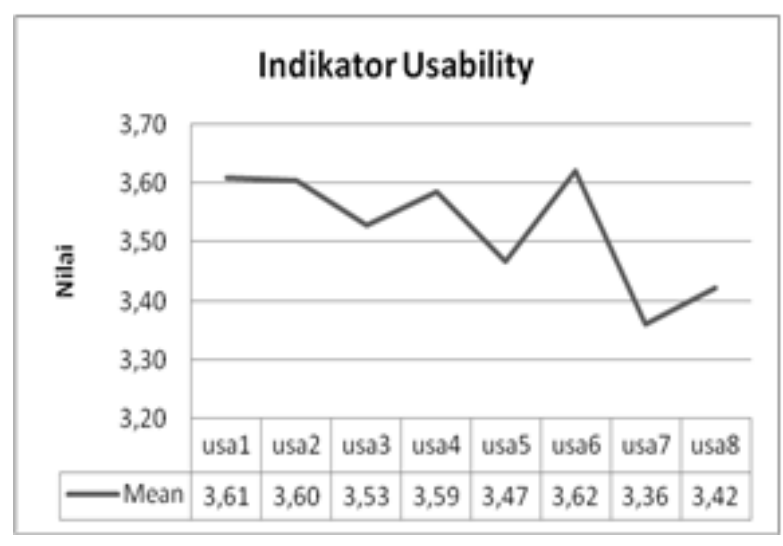

Gambar 5. Penilaian Indikator Usability

Dua indikator terlihat masih dinilai cukup oleh mahasiswa (USA7 dan USA8). Dimana kandungan kompetensi dalam website SIAKAD perlu ditingkatkan. Situs tersebut masih dominan terkait informasi hasil belajar. Untuk meningkatkan kompetensi yang dibangun perlu dilengkapi fasilitas terkait proses belajar. Proses belajar mengajar berbasis daring perlu dikembangkan dalam aplikasi SIAKAD, sehingga mahasiswa bisa meningkatkan kompetensi akademiknya secara interaktif dan mandiri melalui SIAKAD.

\subsubsection{Analisa Dimensi Information Quality}

Hasil analisis pada dimensi kualitas informasi (information quality) terdapat 7 pertanyaan penelitian, jawaban yang paling sering dinyatakan adalah setuju sebanyak 790 (36,29\%) dan jawaban sangat setuju sebanyak 366 $(16,81 \%)$. Jumlah jawaban keduanya muncul 1156 kali $(53,10 \%)$. Jawaban responden cenderung setuju terhadap aspek kualitas informasi yang disajikan di website SIAKAD.

Dalam tabel 4 terdapat indikator yang menjadi perhatian bagi pengguna dan memiliki skor tertinggi adalah indikator "Website memberikan informasi yang detail pada level yang tepat" (INF6), dipersepsikan dengan nilai tertinggi mencapai 3,62 (baik). Indikator hanya mendapatkan nilai cukup yaitu website menyajikan informasi dalam format yang tepat (INF7). Format sajian data SIAKAD perlu ditingkatkan kualitasnya. Secara umum penilaian penggguna website SIAKAD memberikan nilai 3,52 dalam kualitas informasi (information quality) masuk dalam kategori baik.

Tabel 4. Kriteria Penilaian Dimensi Information Quality

\begin{tabular}{ccccc}
\hline Kode & Jumlah & Total & Mean & Kategori \\
\hline INF1 & 311 & 1086 & 3,49 & Baik \\
\hline INF2 & 311 & 1121 & 3,60 & Baik \\
\hline INF3 & 311 & 1097 & 3,53 & Baik \\
\hline INF4 & 311 & 1115 & 3,59 & Baik \\
\hline INF5 & 311 & 1078 & 3,47 & Baik \\
\hline INF6 & 311 & 1126 & 3,62 & Baik \\
\hline INF7 & 311 & 1045 & 3,36 & Cukup \\
\hline Jumlah & 2177 & 7668 & 3,52 & Baik \\
\hline$\%$ & 100 & & &
\end{tabular}

Dalam penilaian dimensi kualitas informasi oleh mahasiswa yang diperlihatkan dalam gambar 6, terlihat 3 indikator yang menjadi puncak penilaian (INF2, INF4 dan INF 6). Mahasiswa merasa bahwa informasi yang disajikan dalam SIAKAD sudah relevan dan detail informasinya sudah tepat. Tingkat kepercayaan mahasiswa terhadap informasi siakad sudah baik. 
ISSN 2614-5278 (media cetak), ISSN 2548-8368 (media online)

Available Online at https://ejurnal.stmik-budidarma.ac.id/index.php/mib DOI 10.30865/mib.v5i3.3046

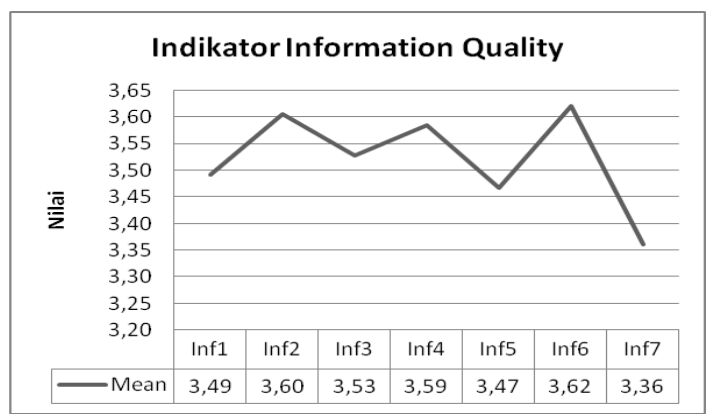

Gambar 6. Penilaian Indikator Information Quality

Mahasiswa juga merasa mudah mengerti dengan konten informasi SIAKAD. Akurasi informasi juga dinilai baik dan up to date (INF1, INF3, dan INF5). Namun demikian penyajian informasi SIAKAD hanya dinilai cukup oleh mahasiswa (INF7). Maka perlu ditingkatan kualitas penataan informasi dan perbaikan format sajian informasi.

\subsubsection{Analisa Dimensi Interaction Quality}

Hasil analisis pada dimensi kualitas interaksi (interaction quality) terdiri dari 7 pertanyaan penelitian dimana responden lebih sering menjawab setuju sebanyak 735 kali $(33,76 \%)$ dan jawaban sangat setuju sebanyak 345 (15,85\%). Jumlah jawaban keduanya muncul 1080 kali (49,70\%). Jawaban responden cenderung setuju terhadap aspek kualitas interaksi yang disajikan di website SIAKAD.

Pada tabel 5 menunjukkan indikator dengan skor tertinggi yang menjadi perhatian bagi pengguna adalah indikator "Pengguna merasa yakin bahwa layanan website sebagaimana yang telah dijanjikan (INT7)", dipersepsikan dengan nilai tertinggi mencapai 3,55 (baik). Indikator yang hanya mendapatkan nilai cukup yaitu website memberikan ruang untuk komunitas (INT5). Website SIAKAD perlu ditambah ruang interaksi dengan sesama penggunanya. Secara umum penilaian penggguna website siakad memberikan nilai 3,46 dalam Kualitas Interaksi (interaction quality) masuk dalam kategori baik.

Tabel 5. Kriteria Penilaian Interaction Quality

\begin{tabular}{ccccc}
\hline Kode & Jumlah & Total & Mean & Kategori \\
\hline INT1 & 311 & 1075 & 3,46 & Baik \\
INT2 & 311 & 1087 & 3,50 & Baik \\
INT3 & 311 & 1067 & 3,43 & Baik \\
INT4 & 311 & 1075 & 3,46 & Baik \\
INT5 & 311 & 1010 & 3,25 & Cukup \\
INT6 & 311 & 1108 & 3,56 & Baik \\
INT7 & 311 & 1105 & 3,55 & Baik \\
Jumlah & 2177 & 7527 & 3,46 & Baik \\
$\%$ & 100 & & & \\
\hline
\end{tabular}

Penilaian mahasiswa dalam dimensi kualitas interaksi dapat ditunjukkan pada gambar 7, dimana 2 indikator menjadi puncak perhatian mahasiswa dinilai baik (INT6 dan INT7). Mahasiswa menilai layanan website SIAKAD sudah seperti yang dijanjikan. Mahasiswa merasa mudah menggunakannya untuk melakukan komunikasi dengan kampus. Kelancaran komunikasi mahasiswa dengan kampus akan menjamin problematika akademis dengan cepat bisa diantisipasi.

Reputasi website SIAKAD dinilai baik karena keamanan data terjaga. Terdapat ruang personalisasi dalam website dan informasi pribadi dinilai terjaga keamanannya (INT1, INT2, INT3 dan INT4). Indikator yang dinilai cukup adalah ketersediaan ruang komunitas. Fasilitas chat group diantara mahasiswa bisa difasilitasi guna melakukan komunikasi, diskusi diantara mahasiswa dalam aktifitas akademik. Fasilitas ini sangat membantu mahasiswa terutama untuk bimbingan skripsi secara online, khususnya di era pandemi covid-19 saat ini.

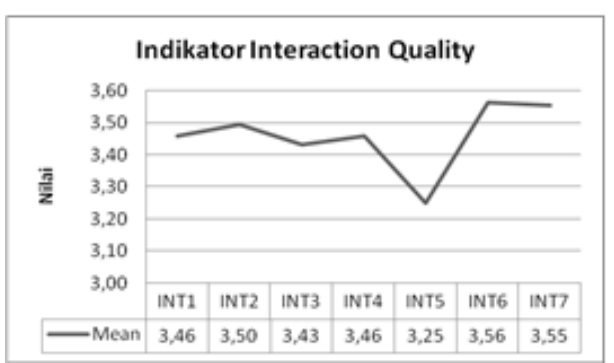

Gambar 7. Penilaian Indikator Interaction Quality 
ISSN 2614-5278 (media cetak), ISSN 2548-8368 (media online)

Available Online at https://ejurnal.stmik-budidarma.ac.id/index.php/mib DOI 10.30865/mib.v5i3.3046

\subsection{Hasil Analisa PIECES Framework}

Analisa PIECES Framework meliputi 6 dimensi, yaitu : Dimensi Performance, Dimensi Information, Dimensi Economic, Dimensi Control, Dimensi Efficiency dan Dimensi Service.

\subsubsection{Analisa Dimensi Performance}

Hasil analisis yang ditunjukkan pada dimensi performance, jawaban dari responden terhadap 7 pertamyaan penelitian yang paling sering adalah menyatakan setuju, yaitu sebanyak 1006 kali $(46,21 \%)$ dan jawaban sangat setuju sebanyak $476(21,86 \%)$. Jumlah jawaban keduanya muncul 1482 kali $(68,07 \%)$. Jawaban responden cenderung setuju terhadap kualitas performance pada website SIAKAD.

Pada tabel 6 tampak indikator yang mempunyai skor tertinggi menjadi perhatian pengguna adalah indikator "Konsistensi (P6)", dipersepsikan dengan nilai tertinggi mencapai 4,22 (baik). Keseragaman dalam penggunaan desain dan teknik dokumentasi dalam sistem dipersepsikan baik oleh penggunanya. Indikator yang hanya mendapatkan nilai cukup yaitu respon time (P2).

Proses kerja sistem website SIAKAD perlu ditingkatkan respon dari transaksi dan dikurangi delay rata-rata antara transaksi. Secara umum penilaian penggguna dalam performance pada website SIAKAD memberikan nilai 3,78 masuk dalam kategori baik.

Tabel 6. Kriteria Penilaian Dimensi Performance

\begin{tabular}{ccccc}
\hline Kode & Jumlah & Total & Mean & Kategori \\
\hline P1 & 311 & 1093 & 3,51 & Baik \\
P2 & 311 & 959 & 3,08 & Cukup \\
P3 & 311 & 1226 & 3,94 & Baik \\
P4 & 311 & 1239 & 3,98 & Baik \\
P5 & 311 & 1212 & 3,90 & Baik \\
P6 & 311 & 1312 & 4,22 & Baik \\
P7 & 311 & 1188 & 3,82 & Baik \\
Jml & 2177 & 8229 & 3,78 & Baik \\
$\%$ & 100 & & & \\
\hline
\end{tabular}

Grafik penilaian mahasiswa yang ditampilkan pada gambar 8 menunjukkan 5 indikator performance dinilai baik oleh mahasiswa (P3, P4, P5, P6, dan P7). Mahasiswa menilai fungsi kerja sistem sudah seperti standar yang ditetapkan dan memiliki fungsi kerja yang lengkap. Desain interface dan teknik dokumentasi dalam SIAKAD dinilai baik serta mudah difahami oleh mahasiswa. Unjuk kerja sistem masih dinilai cukup (P2), perlu ditingkatakan kualitas kinerja sistem dengan dukungan server yang berkualitas baik.

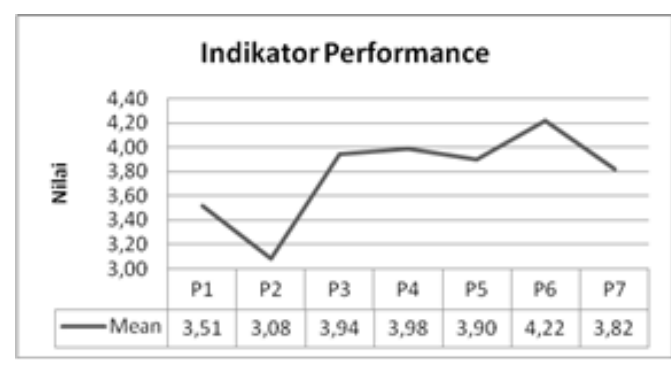

Gambar 8. Penilaian Indikator Performance

\subsubsection{Analisa Dimensi Information}

Hasil analisis yang ditunjukkan pada dimensi information/data terdapat 4 pertanyaan penelitian, jawaban yang paling sering dinyatakan adalah setuju sebanyak 526 kali $(42,28 \%)$ dan jawaban sangat setuju sebanyak 457 $(36,74 \%)$. Jumlah jawaban keduanya muncul 983 kali $(79,02 \%)$. Jawaban responden cenderung setuju terhadap kualitas information/data pada website SIAKAD.

Dalam tabel 7 tampak indikator yang mempunyai skor tertinggi menjadi perhatian pengguna adalah indikator "Fleksibilitas Data (I4)", dipersepsikan dengan nilai tertinggi mencapai 4,28 (sangat baik). Data SIAKAD sangat mudah diakses atau digunakan oleh pengguna. Secara umum penilaian penggguna terhadap kualitas information/data pada website SIAKAD memberikan nilai 4,09 masuk dalam kategori baik.

Tabel 7. Kriteria Penilaian Dimensi Information/Data

\begin{tabular}{ccccc}
\hline Kode & Jumlah & Total & Mean & Kategori \\
\hline I1 & 311 & 1264 & 4,06 & Baik \\
I2 & 311 & 1221 & 3,93 & Baik \\
I3 & 311 & 1276 & 4,10 & Baik \\
\hline
\end{tabular}


ISSN 2614-5278 (media cetak), ISSN 2548-8368 (media online)

Available Online at https://ejurnal.stmik-budidarma.ac.id/index.php/mib DOI 10.30865/mib.v5i3.3046

\begin{tabular}{ccccc}
\hline Kode & Jumlah & Total & Mean & Kategori \\
\hline I4 & 311 & 1332 & 4,28 & Sangat Baik \\
Jml & 1244 & 5093 & 4,09 & Baik \\
$\%$ & 100 & & & \\
\hline
\end{tabular}

Dalam gambar 9 menunjukkan semua indikator dalam dimensi information/data dinilai baik (I1, I2, I3). Proses komputasi dari SIAKAD dinilai baik. Tampilan informasi sudah sesuai harapan dan kebutuhan. Bahkan mahasiswa menilai website SIAKAD sangat mudah untuk diakses/digunakan (I4).

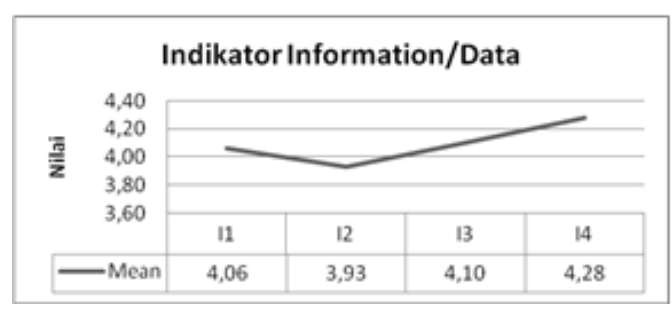

Gambar 9. Penilaian Indikator information/data

\subsubsection{Analisa Dimensi Economic}

Hasil analisis yang ditunjukkan pada dimensi economic ada 2 pertanyaan penelitian dimana responden lebih sering menjawab setuju sebanyak 312 kali $(50,16 \%)$ dan jawaban sangat setuju sebanyak 177 (28,46\%). Jumlah jawaban keduanya muncul 489 kali $(78,62 \%)$. Jawaban responden cenderung setuju terhadap nilai efisiensi atau economic pada website SIAKAD.

Dalam tabel 8 tampak indikator yang mempunyai skor tertinggi menjadi perhatian pengguna adalah indikator "Sumber Daya (EC2)", dipersepsikan dengan nilai tertinggi mencapai 4,16 (baik). Dipersepsikan sedikitnya penggunaan sumber daya yang diperlukan dalam mengembangkan sistem ini. Secara umum penilaian penggguna dalam dimensi economic pada website SIAKAD memberikan nilai 4,04 masuk dalam kategori baik.

Tabel 7. Kriteria Penilaian Dimensi Economic

\begin{tabular}{ccccc}
\hline Kode & Jumlah & Total & Mean & Kategori \\
\hline EC1 & 311 & 1219 & 3,92 & Baik \\
EC2 & 311 & 1294 & 4,16 & Baik \\
Jml & 622 & 2513 & 4,04 & Baik \\
$\%$ & 100 & & & \\
\hline
\end{tabular}

Penilaian indikator dimensi economic gambar 10 mahasiswa memberi nilai baik. SIAKAD dapat dikembangkan dan digunakan kembali dalam aplikasi lain yang berbasis PC maupun android. Serta dikembangkan untuk menunjang sistem pembelajaran daring. Sumber daya internal bisa digunakan untuk mengembangkan program karena basis perguruan tinggi adalah ilmu komputer, sehingga efisien dalam penggunaan sumberdaya.

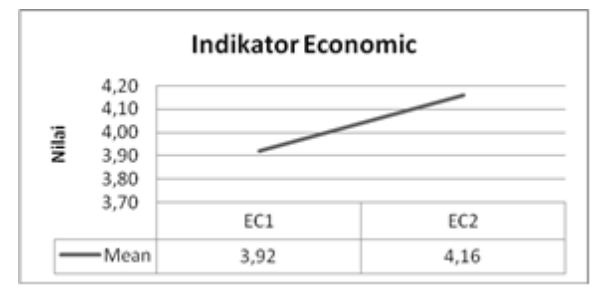

Gambar 10. Penilaian Indikator Economic

\subsubsection{Analisa Dimensi Control}

Tabel 9 menunjukkan hasil analisis dalam dimensi control/security. Terdapat 2 pertanyaan yang disajikan, terlihat yang sering muncul dari jawaban responden adalah setuju, yaitu sebanyak 286 kali $(45,98 \%)$ dan jawaban sangat setuju sebanyak $216(34,73 \%)$. Jumlah jawaban keduanya muncul 502 kali (80,71 \%). Jawaban responden cenderung setuju terhadap aspek Kualitas control/security dalam website SIAKAD.

Dalam tabel 9 terlihat indikator yang mempunyai skor tertinggi menjadi perhatian bagi pengguna adalah indikator Integritas (C1), dipersepsikan dengan nilai tertinggi mencapai 4,28 (sangat baik). Dimana dipersepsikan pengguna bahwa akses ke sistem atau data oleh orang yang tidak berhak dapat dikontrol. Secara umum penilaian penggguna website SIAKAD memberikan nilai 4,12 dalam kualitas control/security masuk dalam kategori baik. 
ISSN 2614-5278 (media cetak), ISSN 2548-8368 (media online)

Available Online at https://ejurnal.stmik-budidarma.ac.id/index.php/mib DOI 10.30865/mib.v5i3.3046

Tabel 7. Kriteria Penilaian Dimensi Economic

\begin{tabular}{ccccc}
\hline Kode & Jumlah & Total & Mean & Kategori \\
\hline C1 & 311 & 1330 & 4,28 & Sangat Baik \\
C2 & 311 & 1234 & 3,97 & Baik \\
Jml & 622 & 2564 & 4,12 & Baik \\
$\%$ & 100 & & & \\
\hline
\end{tabular}

Penilaian indikator Integritas (C1) dalam dimensi control/security pada gambar 11 menunjukkan hasil yang sangat baik. Sistem memiliki kesesuaian batasan akses terhadap operator program. Sedangkan indikator security (C2) dinilai baik dimana sistem mampu menjaga dengan baik keamanan data yang disimpan.

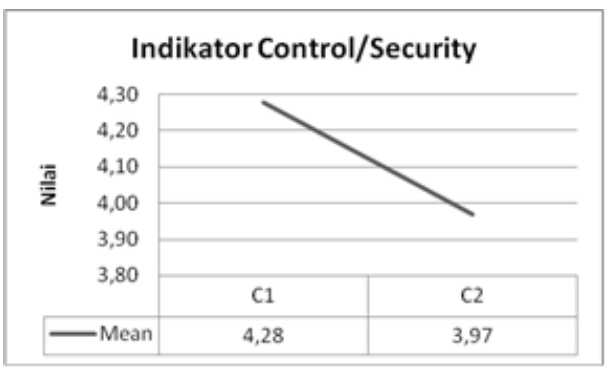

Gambar 11. Penilaian Indikator Control/security

\subsubsection{Analisa Dimensi Efficiency}

Hasil analisis yang ditunjukkan dalam dimensi efficiency, dari 2 pertanyaan yang disajikan, maka jawaban responden yang sering muncul adalah setuju yaitu sebanyak 238 kali $(38,26 \%)$ dan jawaban sangat setuju sebanyak 247 (39,71 \%). Jumlah jawaban keduanya muncul 485 kali (77,97 \%). Jawaban responden cenderung setuju terhadap nilai efficiency pada website SIAKAD.

Dalam tabel 10 terlihat indikator yang mempunyai skor tertinggi menjadi perhatian bagi pengguna adalah indikator usabilitas (EF1), dipersepsikan dengan nilai tertinggi mencapai 4,26 (sangat baik). Dimana pengguna merasa mudah untuk mempelajari dan mengoperasikan sistem SIAKAD. Secara umum penilaian penggguna website SIAKAD memberikan nilai 4,13 dalam nilai efficiency masuk dalam kategori baik.

Tabel 10. Kriteria penilaian Dimensi Efficiency

\begin{tabular}{ccccc}
\hline Kode & Jumlah & Total & Mean & Kategori \\
\hline EF1 & 311 & 1326 & 4,26 & Sangat Baik \\
\hline EF2 & 311 & 1242 & 3,99 & Baik \\
\hline Jml & 622 & 2568 & 4,13 & Baik \\
\hline$\%$ & 100 & & & \\
\hline
\end{tabular}

Penilaian mahasiswa terhadap dimensi efficiency menunjukkan hasil yang baik, seperti terlihat dalam grafik gambar 12. Dalam indikator usabilitas (EF1) dinilai sangat baik, dimana mahasiswa merasa mudah dalam mempelajari sistem. Mahasiswa tidak kesulitan dalam menggunakan SIAKAD.

Indikator Maintanabilitas (EF2) juga dinilai baik. Kesalahan yang terjadi dalam sistem mudah diidentifikasi, dan mudah untuk segera dibetulkan. Kesalahan yang terjadi kebanyakan pada human error dalam input data.

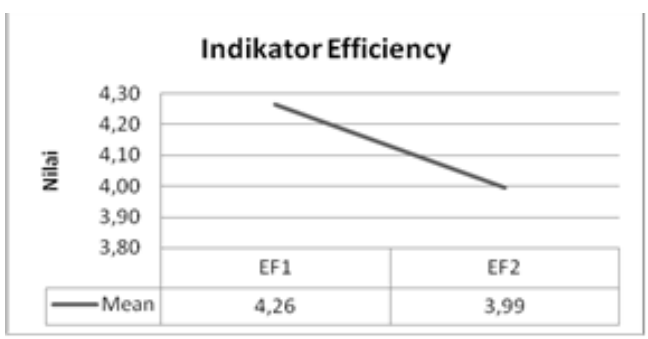

Gambar 12. Penilaian Indikator Efficiency

\subsubsection{Analisa Dimensi Service}

Hasil analisis dalam dimensi service, dimana jawaban responden terhadap 3 pertamyaan penelitian yang paling sering adalah menyatakan setuju, yaitu sebanyak 464 kali $(49,73 \%)$ dan jawaban sangat setuju sebanyak 270 $(28,94 \%)$. Jumlah jawaban keduanya muncul 734 kali $(78,67 \%)$. Jawaban responden cenderung setuju terhadap aspek kualitas service dalam website SIAKAD. 
Dalam tabel 11 terlihat indikator yang mempunyai skor tertinggi menjadi perhatian bagi pengguna adalah indikator akurasi (S1), dipersepsikan dengan nilai tertinggi mencapai 4,22 (baik). Dimana sistem SIAKAD dianggap oleh pengguna memiliki ketelitian dalam melakukan proses kerja. Secara umum penilaian penggguna website SIAKAD memberikan nilai 4,02 dalam dimensi service, masuk dalam kategori baik.

Tabel 11. Kriteria penilaian Dimensi Service

\begin{tabular}{ccccc}
\hline Kode & Jumlah & Total & Mean & Kategori \\
\hline S1 & 311 & 1312 & 4,22 & Baik \\
S2 & 311 & 1182 & 3,80 & Baik \\
S3 & 311 & 1257 & 4,04 & Baik \\
Jml & 933 & 3751 & 4,02 & Baik \\
$\%$ & 100 & & & \\
\hline
\end{tabular}

Gambar 13 menunjukkan grafik penilaian mahasiswa terhadap dimensi service. Dimana indikator akurasi (S1) dinilai baik, sistem oleh mahasiswa dianggap mampu melakukan kerja dengan teliti. Mahasiswa percaya sistem mampu melakukan pekerjaan yang diminta, sehingga menilai baik indikator reliabilitas (S2). Mahasiswa juga menilai baik indikator kesederhanaan (S3), dimana sistem dianggap mudah untuk dipahami dalam penggunaannya

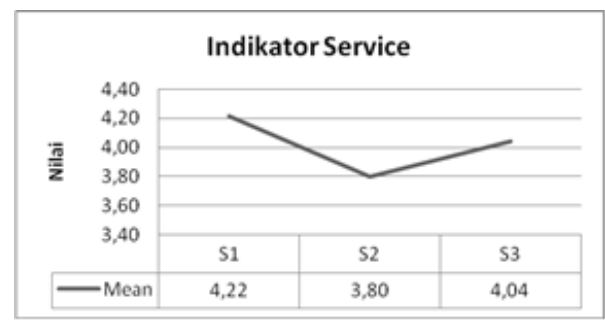

Gambar 13. Penilaian Indikator Service

Analisa WebQual digunakan untuk mengukur kualitas website SIAKAD berdasarkan persepsi pengguna. Hasil penilaian pengguna dengan metode ini dilihat dalam tabel 12, menghasilkan nilai kualitas website SIAKAD dengan kategori baik.

Tabel 12. Hasil analisa Dimensi Webqual

\begin{tabular}{ccccc}
\hline Dimensi & Jumlah & Total & Mean & Kategori \\
\hline Dimensi Kemudahan Penggunaan (usability) & 2392 & 8442 & 3,52 & Baik \\
Dimensi Kualitas informasi (information quality) & 2177 & 7668 & 3,52 & Baik \\
Dimensi Kualitas Interaksi (interaction quality) & 2173 & 7519 & 3,46 & Baik \\
Jumlah & 6742 & 23629 & 3,50 & Baik \\
\hline
\end{tabular}

Analisa PIECES framework yang digunakan untuk mengukur kualitas website SIAKAD, menghasilkan nilai kualitas dengan kategori baik, sebagaimana terlihat dari tabel 13.

Tabel 13. Hasil Analisa PIECES Frameworks

\begin{tabular}{ccccc}
\hline Dimensi & Jml & Total & Mean & Kategori \\
\hline Performance & 2177 & 8229 & 3,78 & Baik \\
Information/Data & 1244 & 5093 & 4,09 & Baik \\
Economic & 622 & 2513 & 4,04 & Baik \\
Control/Security & 622 & 2564 & 4,12 & Baik \\
Efficiency & 622 & 2568 & 4,13 & Baik \\
Service & 933 & 3751 & 4,02 & Baik \\
\hline
\end{tabular}

Hasil analisa dengan metode WebQual dan PIECES framework terhadap kualitas website Sistem Informasi Akademik (SIAKAD) menghasilkan hasil yang sama yaitu penilaian dengan kategori baik. Hal ini tergambarkan dalam uraian berikut :

\section{Kinerja program sudah baik.}

Mahasiswa menilai baik fungsi kerja sistem, diantaranya : memiliki fungsi kerja yang lengkap. Sudah seperti standar yang ditetapkan. Proses komputasi yang baik. Mampu melakukan kerja dengan teliti. Mampu melakukan pekerjaan yang diminta dan SIAKAD dapat dikembangkan serta digunakan kembali dalam aplikasi lain yang berbasis PC maupun android. Kesalahan yang terjadi dalam sistem mudah diidentifikasi, dan mudah untuk segera dibetulkan.

\section{Sistem mudah dipelajari.}


Mahasiswa menerasa tidak kesulitan dalam mempelajari dan mudah memahami interaksi dalam website SIAKAD .

3. Sistem mudah digunakan.

Mahasiswa mudah untuk memahami dan menggunakan sistem, ditandai dalam kemudahan berinteraksi, bernavigasi dan mengakses website SIAKAD.

4. Penyajian informasi yang baik.

Desainnya sudah dianggap sesuai dan menarik. Desain interface dan teknik dokumentasi dalam SIAKAD dinilai baik serta mudah difahami oleh mahasiswa. Tampilan informasi sudah sesuai harapan dan kebutuhan.

5. Konten Informasi sesuai harapan dan kebutuhan,

Mahasiswa merasa bahwa informasi yang disajikan dalam SIAKAD sudah relevan dan detail informasinya sudah tepat. Tingkat kepercayaan mahasiswa terhadap informasi siakad sudah baik. Mahasiswa juga merasa mudah mengerti kandungan informasi SIAKAD. Akurasi informasi juga dinilai baik dan up to date.

6. Pelayanan/Service sistem baik

Dimana mahasiswa menilai layanan website SIAKAD sudah seperti yang dijanjikan. Mahasiswa merasa mudah menggunakannya untuk melakukan komunikasi dengan kampus. Kelancaran komunikasi mahasiswa dengan kampus akan menjamin problematika akademis dengan cepat bisa diantisipasi.

7. Kemananan sistem baik dan kepercayaan pengguna terhadap sistem tinggi

Mahasiswa percaya terhadap data yang diberikan. Reputasi website SIAKAD dinilai baik karena keamanan data dan informasi pribadi terjaga.

Penelitian ini juga menghasilkan rekomendasi pengembangan dan perbaikan guna meningkatkan kualitas website SIAKAD, meliputi :

1. Kandungan kompetensi dalam website SIAKAD perlu ditingkatkan terutama terkait kompetensi akademik dosen dan mahasiswa

2. Pengembangan program yang menunjang sistem pembelajaran daring.

3. Peningkatan kualitas penataan informasi dan perbaikan format sajian informasi.

4. Pengembangan ruang komunitas. Fasilitas chat group diantara mahasiswa bisa difasilitasi guna melakukan komunikasi, diskusi diantara mahasiswa dalam aktifitas akademik.

5. Memperbanyak dan melengkapi output yang dihasilkan SIAKAD.

6. Unjuk kerja sistem masih perlu ditingkatakan dengan dukungan server yang berkualitas baik.

\section{KESIMPULAN}

Penelitian ini menganalisa data persepsi mahasiswa terhadap kualitas website Sistem Informasi Akademik (SIAKAD), menggunakan analisa WebQual diperoleh nilai 3,50 dan analisa PIECES Framework dengan nilai 3,97 yang masuk kategori Baik dengan nilai skor 4 berdasarkan kriteria penilaian berdasarkan kombinasi skala likert dan interval kelas seperti yang terlampir tabel dua kriteria penilaian. Kedua metode tersebut memberikan hasil yang sama yaitu penilaian dengan kategori baik. Hasil rekomendasi pada penelitian ini diharapkan dapat memberikan kontribusi kepada manajemen perguruan tinggi sebagai salah satu bahan acuan / pendukung keputusan dalam meningkatkan kualitas sistem informasi akademik (SIAKAD) berbasis aplikasi website.

\section{UCAPAN TERIMAKASIH}

Ucapan terimakasih kepada Universitas Kristen Satya Wacana (UKSW) fakultas magister sistem informasi sebagai perguruan tinggi yang mendukung adanya gagasan dan kontribusi akan pengetahuan khususnya bagi para mahasiswa dan dosen dalam melakukan kolaborasi penelitian.

\section{REFERENCES}

[1] C. Ang and M. R. Ridho, "Analisis Kualitas Sistem Informasi PT Riway International Terhadap Kepuasan Member Menggunakan Metode Webqual 4.0," Comput. Sci. Ind. Eng., vol. 4, no. 3, pp. 134-143, 2021.

[2] J. Hutahaean, Konsep Sistem Informasi. Deepublish, 2018.

[3] M. Rakhmadian, S. Hidayatullah, H. Respati, and U. M. Malang, "Analisis Kualitas Sistem Dan Kualitas Informasi Terhadap Kepuasan Pemakai Sistem Informasi Akademik Dosen,” Semin. Nas. Sist. Inf., no. September, pp. 665-675, 2017.

[4] A. Hermanto, S. Supangat, and F. Mandita, "Evaluasi Usabilitas Layanan Sistem Informasi Akademik Berdasarkan Kombinasi ServQual dan Webqual Studi Kasus : SIAKAD Politeknik XYZ," J. Inf. Syst. Eng. Bus. Intell., vol. 3, no. 1, p. 33, 2017.

[5] Nurbojatmiko, N. I. R. Taufiqiya, D. Al Aziz, M. I. Shiddiq, and M. Musri, "Penilaian Layanan Infrastruktur Seluler Berbasis Pengguna Menggunakan Framework PIECES (Studi Kasus: PT. XL Axiata Tbk di Wilayah Bojong Sari, Kota Depok)," J. SEBATIK, vol. 23, no. 1, pp. 165-171, 2019.

[6] U. Husein, Nurhadi, and Mulyadi, "Pengukuran Kualitas Website Sistem Informasi Akademik STIKOM Dinamika Bangsa Jambi," Indones. J. Comput. Inf. Technol., vol. 4, no. 2, pp. 147-154, 2019. 
ISSN 2614-5278 (media cetak), ISSN 2548-8368 (media online)

Available Online at https://ejurnal.stmik-budidarma.ac.id/index.php/mib DOI 10.30865/mib.v5i3.3046

[7] A. Mustopa, S. Agustiani, S. K. Wildah, and M. Maysaroh, "Analisa Kepuasan Pengguna Website Layanan Akademik Kemahasiswaan (LYKAN) UBSI Menggunakan Metode Webqual 4.0,” J. Perspekt., vol. 18, no. 1, pp. 75-81, 2020.

[8] D. Suhartanto, M. Helmi Ali, K. H. Tan, F. Sjahroeddin, and L. Kusdibyo, "Loyalty toward online food delivery service: the role of e-service quality and food quality," J. Foodserv. Bus. Res., vol. 22, no. 1, pp. 81-97, 2019.

[9] Y. K. Kumarahadi, W. W. Winarno, and M. P. Kurniawan, "D\&M IS Success Model dan WebQual 4.0 pada Siakad Online STMIK Sinar Nusantara Surakarta,” J. Ilm. SINUS, vol. 18, no. 1, p. 25, 2020.

[10] A. Jamalludin, Sulistiowati, and J. Lemantara, "Analisis Pengaruh Kualitas Website Terhadap Kepuasan Pengguna Berdasarkan Metode Webqual 4.0 pada Website Stikom Career Center (SCC) Surabaya," J. Sist. Inf. dan Komput. Akunt., vol. 5, no. 1, pp. 159-172, 2016.

[11] J. Simarmata, Rekayasa Web. Andi, 2010.

[12] H. Aryadita, Himawat; Widyastuti, Dyah; Wardani, Niken, "Analisis Kualitas Layanan Website E-commerce Terhadap Kepuasan Pengguna Menggunakan Metode Webqual 4.0," Stud. Inform. J. Sist. Inf., vol. 10, no. 1, pp. 29-35, 2017.

[13] H. O. L. Wijaya and P. ; B. Mandala, "Evaluasi Website Open Journal System Menggunakan Metode Webqual," J. Teknol. Inf. Mura, vol. 12, no. 01, pp. 68-75, 2020.

[14] A. Supriyatna and V. Maria, "Analisa Tingkat Kepuasan Pengguna dan Tingkat Kepentingan Penerapan Sistem Informasi DJP Online dengan Kerangka PIECES,” Khazanah Inform. J. Ilmu Komput. dan Inform., vol. 3, no. 2, p. 88, 2018.

[15] P. L. Lokapitasari Belluano, I. Indrawati, H. Harlinda, F. A. . Tuasamu, and D. Lantara, "Analisis Tingkat Kepuasan Pengguna Sistem Informasi Perpustakaan Menggunakan PIECES Framework,” Ilk. J. Ilm., vol. 11, no. 2, pp. 118-128, 2019.

[16] W. Supriyanto and R. Iswandari, "Kecenderungan Sivitas Akademika dalam Memilih Sumber Referensi untuk Penyusunan Karya Tulis Ilmiah di Perguruan Tinggi,” Berk. Ilmu Perpust. dan Inf., vol. 13, no. 1, p. 79, 2017.

[17] I. Ghozali, Aplikasi Analisis Multivariete Dengan Program IBM SPSS 23 (Edisi 8). Cetakan ke VIII. 2016. 